\title{
Analysis of the Content of Hydrogen Sulfide in the Air of the City of Atyrau
}

\author{
Mansiya Yessenamanova*, Zhanar Yessenamanova, Anar Tlepbergenova, Gaukhar Batyrbayeva \\ Department of “Ecology”, Kh.Dosmukhamedov Atyrau University, Atyrau 060001, Republic of Kazakhstan
}

Corresponding Author Email: m.esenamanova@asu.edu.kz

https://doi.org/10.18280/ijsdp.160308

Received: 7 March 2021

Accepted: 20 May 2021

\section{Keywords:}

hydrogen sulfide, maximum permissible concentrations, Pollution Observation Point

\begin{abstract}
This study is aimed at analyzing the content of hydrogen sulfide in the air of the city of Atyrau, located in the northern part of the Caspian Sea of the Republic of Kazakhstan. The analysis was carried out on the basis of monitoring the indicators of the Republican State Enterprise "Kazhydromet" from 8 points located in different directions from the Atyrau oil refinery. Measurements of atmospheric air pollution are made by the GANK-4AR gas analyzer designed for continuous automatic measurement of concentrations of pollutants in the atmospheric air. Hydrogen sulfide was selected as an indicator air pollutant. Atyrau oil refinery is the main object of pollution of the territory of the city of Atyrau, located in the western part of the Republic of Kazakhstan, on the shore of the Caspian Sea. The results obtained show that the content of hydrogen sulfide in the territory of the city of Atyrau in most places shows an excess of the maximum permissible concentration. Especially the excess is observed in the north-western part up to 4-8 maximum permissible concentrations. At two points (in the northeastern and western parts), the content of hydrogen sulfide did not exceed the maximum permissible concentration.
\end{abstract}

\section{INTRODUCTION}

The oil industry plays a huge role in the global economy, being one of the most intense sources of environmental pollution. The danger to the health of the population living in the zone of exposure to emissions from the petrochemical and oil refining industries, described in the works of Baktybayeva, Badalians Gholikandi, Beksultan, Esenamanova, is due to the fact that the composition of emissions is dominated by petroleum gasoline, sulfur dioxide and carbon monoxide, hydrogen sulfide, formaldehydes, soot, compounds of heavy metals and various chemical elements, and other substances [1-5].

Atyrau region occupies a special place among the regions and zones of ecological disaster in Kazakhstan. According to Yessenamanova's research, the ecological situation here is formed under the influence of natural and anthropogenic factors, the most important of which are the rise in the Caspian Sea level and the rapid development of the oil and gas complex [6]. The increase in oil and gas production, the high aggressiveness of the extracted raw materials affect the processes of intensive pollution of the atmosphere, surface and underground waters, and through them-the soil and vegetation cover, in which, according to the works of Yessenamanova, heavy metals, radionuclides accumulate [7] and petroleum products [8]. In the Atyrau region, solid particles, sulfur dioxide, carbon monoxide, nitrogen oxides and hydrocarbons are released into the atmosphere during the operation of oil fields.

Among all the elements, the most significant toxicant is hydrogen sulfide. $\mathrm{H}_{2} \mathrm{~S}$ is an extremely toxic gas that has a negative effect on the human nervous system. Hydrogen sulfide belongs to the third class on the scale of danger to the body. Therefore, you should take this fact into account every time you feel a distinct smell of "rotten eggs". The greatest danger is that the gas blunts the sense of smell and because of this, a person ceases to distinguish between toxic fumes. That is why toxin poisoning can occur unexpectedly.

The lethal dose of hydrogen sulfide in the air is only $0.1 \%$, but even such a small amount of gas can lead to death in less than 10 minutes. If its level of content is higher, then death can occur from one breath. For comparison, the concentration of $\mathrm{H}_{2} \mathrm{~S}$ in the sewer is $16 \%$.

Eunjung's research shows that the main signs of toxic gas poisoning are: pulmonary edema, severe convulsions, nervous paralysis, coma [9].

If the gas content in the atmosphere is from $0.02 \%$, it will not lead to sad consequences, but, nevertheless, the symptoms will be pronounced: severe headaches, nausea, frequent dizziness.

People who live or work near factories that emit hydrogen sulfide into the air suffer from chronic poisoning. With such a long stay, according to Efimova's research, symptoms such as fainting, rapid weight loss, a metallic taste in the mouth, visual impairment, and photophobia appear in the immediate vicinity of $\mathrm{H}_{2} \mathrm{~S}$ [10].

MPC of hydrogen sulfide $\left(\mathrm{H}_{2} \mathrm{~S}\right)$ in the air in the working area $-10 \mathrm{mg} / \mathrm{m}^{3}$, in a mixture with hydrocarbons $-3 \mathrm{mg} / \mathrm{m}^{3}$.

The maximum permissible concentration (MPC) of hydrogen sulfide $\left(\mathrm{H}_{2} \mathrm{~S}\right)$ specified in the work of Yeler, in the air of populated areas is $0.008 \mathrm{mg} / \mathrm{m}^{3}$ [11].

A noticeable smell of hydrogen sulfide is observed at a concentration of hydrogen sulfide of $1.4-2.3 \mathrm{mg} / \mathrm{m}^{3}$, a significant smell-at $4 \mathrm{mg} / \mathrm{m}^{3}$, a heavy smell at $7-11 \mathrm{mg} / \mathrm{m}^{3}$ [12].

Hydrogen sulfide occurs in nature in its pure form and as a product of processing other substances. Toxic condensate is 
collected on the equipment and walls of the plants ' premises. Industrial water also contains toxic substances. Poisoning is received by workers of city services, cleaning sewers, employees of pumping stations, chemical laboratories, miners. Cases of intoxication in everyday life are recorded extremely rarely. This includes living in an ecologically polluted area, near a faulty sewer system. The air in a polluted area has a rotten smell. According to Ledentsova and Alimbaev's research, workers in the oil, gas and processing industries, pulp and paper, textile industries, farmers, workers in solid and liquid waste landfills, sewage and wastewater treatment plants are at risk $[13,14]$. One of the sources of hydrogen sulfide in the air on the territory of the city of Atyrau is the Atyrau oil refinery.

\section{MATERIAL AND METHODS}

\subsection{Study area}

"Atyrau Oil Refinery" (AOR) LLP is the first-born oil refinery in Kazakhstan. The design of the plant was started in 1943 on the basis of the planned task of the People's Commissariat of the Oil Industry of the USSR. The technical design of the plant was developed by the American firm "Badger and Sons". The adjustment was carried out by the project organization of the State Trust No. 1 of the People's Commissariat of the Oil Industry of the USSR. Linking to local conditions was carried out by local designers "Embaneftproekt". The construction of the plant was carried out in difficult wartime conditions. More than 10 thousand people took part in the construction of the plant. The plant was put into operation on September 8, 1945. The first production of the plant was automobile gasoline.

The total area of the land plot of "AOR" LLP is 239.5862 hectares. In accordance with the intended purpose, the land of "AOR" LLP belongs to the category of industrial land according to paragraph 1 of Article 1 of the Land Code of the Republic of Kazakhstan No. 442-II of June 20, 2003 (as amended as of 30.06.2016).

The site of "AOR" LLP is located on the south-eastern outskirts of Atyrau, in an industrial zone. On the north-eastern side, "AOR" LLP borders on the production sites of the chemical plant and the Atyrau CHPP. On the north-west side, behind the highway that runs along the territory of the plant, there are industrial and administrative buildings and objects of fire-fighting and military service.

The site of "AOR" LLP is located on the south-eastern outskirts of Atyrau, in an industrial zone. As indicated in the work of Mukusheva, on the north-eastern side, "AOR" LLP borders on the production sites of the chemical plant and the Atyrau CHPP. On the north-west side, behind the highway passing through the territory of the plant, there are industrial and administrative buildings, as well as fire and military service facilities [15].

The nearest residential area is located in the north-west direction at a distance of 1320 meters from the extreme source of pollution of AOR LLP.

The flare installation is located on the south-eastern side of the AOR LLP behind the supply and discharge channels of the Atyrau CHPP along the irrigation channel at a distance of 300 meters from the plant.

\subsection{Methods}

Republican State Enterprise "Kazhydromet" conducts round-the-clock monitoring, i.e. observes, analyzes, predicts and warns about the behavior of nature in various environments, namely in the air, water, and soil. Republican State Enterprise "Kazhydromet" is the only legally responsible body that has the right to provide official information services to any organizations with storm warnings about impending dangerous and natural phenomena in the territory of our state. On the website of Republican State Enterprise "Kazhydromet" you can get information on air pollution [16]. All information is recorded on the map with the indication of monitoring points for air pollution. There are 8 points in total, of which 6 units of the PNZ are automatic, and 2 points are manual. The information is available online. In addition, there is a mobile application "Air Kz", which helps to monitor the quality of atmospheric air throughout Kazakhstan. At the posts of the Republican State Enterprise "Kazhydromet", observations are carried out on pollutants-suspended particles PM-2.5, suspended particles PM-10, suspended substances, sulfur dioxide, carbon monoxide, carbon dioxide, nitrogen oxide, nitrogen dioxide, hydrogen sulfide, phenol, formaldehyde, ammonia, ozone, methane and the sum of hydrocarbons. To study the content of hydrogen sulfide in the city of Atyrau, data from this application was analyzed for 32 days (from September 9 to October 10, 2020) and then the data was processed.

Air sampling was carried out in accordance with RD 52.04.186-89 and GOST 17.2.3.01-86 "Atmosphere. Rules for monitoring the air quality of settlements" according to the observation program four times a day at 7:00 a.m, 1:00 p.m., 7:00 p.m. and 1:00 a.m. of local maternity time. Measurements of atmospheric air pollution were made by the GANK-4AR Gas Analyzer (NPO Pribor Russia, Head No. 1566, inv. No. 000000962-21.02.2018 Self-adhesive label HMS No. 54059211 time per year) designed for continuous automatic measurement of concentrations of pollutants in the atmospheric air and in the air of the working area. Hydrogen sulfide was selected as an indicator air pollutant.

\section{RESULTS AND DISCUSSION}

In the city of Atyrau, there are 8 observation Points for monitoring the state of the atmospheric air, which are located in different directions from the Atyrau oil refinery (AOR), which can be seen in Table 1 .

Data on 8 items were taken in the periods September 2020January 2021 in the evening from 10 to 12 hours for the period of one day. Only the parameters of hydrogen sulfide were studied, taking into account its lower, upper and middle parameters. In Figure 1, you can see the indicators for 1 point of POP No.6, which is located at the farthest distance from the Atyrau oil refinery.

The content of hydrogen sulfide in the point of POP No.6 in the period from September to January did not exceed the MPC. In October, there was an excess of the maximum value by 2.5 times (up to $5 \mathrm{mcg} / \mathrm{m}^{3}$ ). The maximum value greater than the MPC by 1.5 times was observed in January $\left(3 \mathrm{mcg} / \mathrm{m}^{3}\right)$. As can be seen from the obtained indicators, in most cases, the excess was noted in the evening. 
Table 1. Locations of observation point for the state of atmospheric air in the city of Atyrau, Republic of Kazakhstan

\begin{tabular}{|c|c|c|c|}
\hline No. & Point title & Point address & $\begin{array}{l}\text { The location of the Point depending on } \\
\text { the Atyrau oil refinery }\end{array}$ \\
\hline 1 & $\begin{array}{c}\text { POP (Pollution } \\
\text { Observation Point) No. } 6\end{array}$ & $\begin{array}{l}\text { Atyrau, st. Bigeldinova, 10A (old airport, next to the } \\
\text { Atyrau branch of the RSE "Kazhydromet") }\end{array}$ & $\begin{array}{l}\text { In the northwestern part }\left(45^{\circ}\right) \text { at a } \\
\text { distance of } 7.0 \mathrm{~km}\end{array}$ \\
\hline 2 & POP No. 5 (manual Point) & Atyrau, corner of Satpayev ave. and st. Vladimirskaya & $\begin{array}{l}\text { In the north-western part }\left(60^{\circ}\right) \text { at a } \\
\text { distance of } 6.1 \mathrm{~km}\end{array}$ \\
\hline 3 & POP No. 1 (manual Point) & Atyrau, Azattyk Ave., corner of Auezov Ave. & $\begin{array}{l}\text { In the north-western part }\left(46^{\circ}\right) \text { at a } \\
\text { distance of } 2.4 \mathrm{~km}\end{array}$ \\
\hline 4 & POP No.2 & Atyrau, Auezov Avenue 88/1 & $\begin{array}{l}\text { In the north-western part }\left(45^{\circ}\right) \text { at a } \\
\text { distance of } 1.6 \mathrm{~km}\end{array}$ \\
\hline 5 & Mirny AOR & Atyrau, Mirny AOR & $\begin{array}{l}\text { In the north-western part }\left(5^{\circ}\right) \text { at a distance } \\
\text { of } 1.8 \mathrm{~km}\end{array}$ \\
\hline 6 & Steaming AOR & Atyrau, Steaming AOR & $\begin{array}{l}\text { In the south-western part }\left(10^{\circ}\right) \text { at a } \\
\text { distance of } 1.9 \mathrm{~km}\end{array}$ \\
\hline 7 & Drag and drop AOR & Atyrau, Drag and drop AOR & $\begin{array}{l}\text { In the south-western part }\left(45^{\circ}\right) \text { at a } \\
\text { distance of } 2.6 \mathrm{~km}\end{array}$ \\
\hline 8 & Himposylok AOR & Atyrau, Himposylok AOR & $\begin{array}{l}\text { In the northeastern part }\left(44^{\circ}\right) \text { at a distance } \\
\text { of } 3.1 \mathrm{~km}\end{array}$ \\
\hline
\end{tabular}

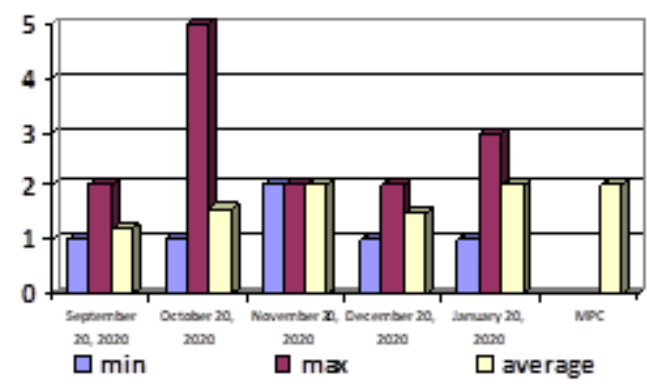

Figure 1. The content of hydrogen sulfide in the point of POP No. 6

Figure 2 shows the indicators for item 2 of the POP No.5.

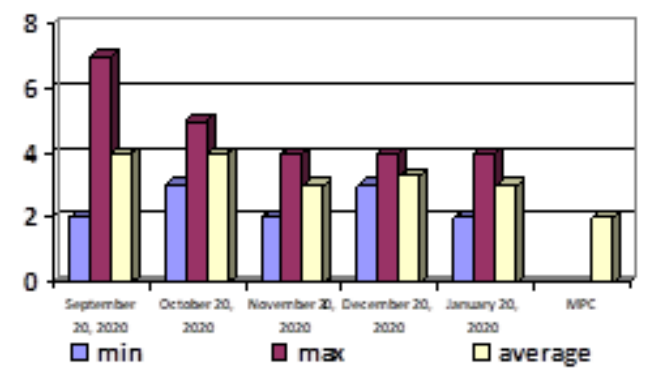

Figure 2. The content of hydrogen sulfide in the point of POP No. 5

As the results for September-January show, the content of hydrogen sulfide at maximum values exceeded the MPC from 2 to 3.5 times (from 4 to $7 \mathrm{mcg} / \mathrm{m}^{3}$ ). The highest value was observed in September, $7 \mathrm{mcg} / \mathrm{m}^{3}$, and in November-January, $4 \mathrm{mcg} / \mathrm{m}^{3}$. On average, the content of hydrogen sulfide exceeds the MPC by up to $1.5-2$ times $\left(3-4 \mathrm{mcg} / \mathrm{m}^{3}\right)$. According to the minimum values, the content of hydrogen sulfide was from 2 to $3 \mathrm{mcg} / \mathrm{m}^{3}$, which was in the range from 1 to $1.5 \mathrm{MPC}$.

Figure 3 shows the indicators for item 3 of the POP No.1.

As the results of point 1 show, in all periods there was an excess of the MPC from the minimum values from 1 to 4 MPC (from 2 to $8 \mathrm{mcg} / \mathrm{m}^{3}$ ). The highest value was observed in the month of October, $8 \mathrm{mcg} / \mathrm{m}^{3}$, and in the month of NovemberJanuary, from 3 to $7 \mathrm{mcg} / \mathrm{m}^{3}$. On average, the content of hydrogen sulfide exceeds the MPC by up to 1.5-2.5 times (3$5 \mathrm{mcg} / \mathrm{m}^{3}$ ). According to the minimum values, the content of hydrogen sulfide is from 2 to $4 \mathrm{mcg} / \mathrm{m}^{3}$, which is in the range from 1 to 2 MPC.

Figure 4 shows the indicators for item 4 of the POP No.2.

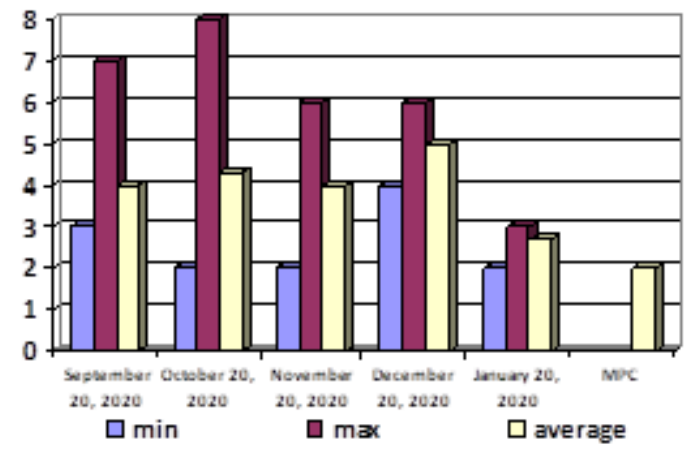

Figure 3. The content of hydrogen sulfide in the point of POP No.1

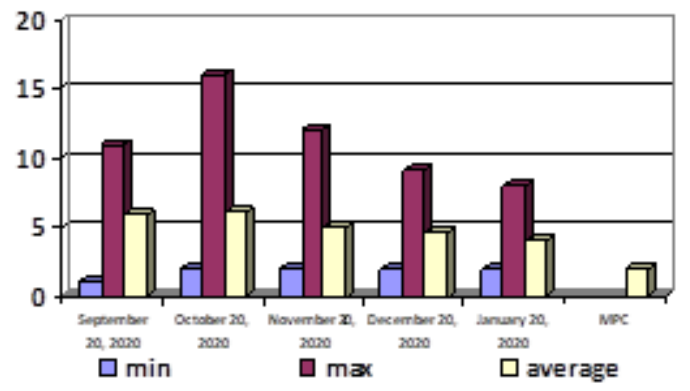

Figure 4. The content of hydrogen sulfide in the point of POP No.2

The results for point 2 show the highest values for the content of hydrogen sulfide. The maximum values were typical for the month of October up to $16 \mathrm{mcg} / \mathrm{m}^{3}$, which is 8 MPC, and also in the rest of the time the maximum value exceeded the MPC up to 4-6 MPC $\left(8-12 \mathrm{mcg} / \mathrm{m}^{3}\right)$. According to the minimum value, the content of hydrogen sulfide was within $1 \mathrm{MPC}$. By an average value it was from 2 to 3 MPC $\left(4-6 \mathrm{mcg} / \mathrm{m}^{3}\right)$. The minimum values were typical for winter periods. 
Figure 5 shows the indicators for item 5 of Mirny AOR.

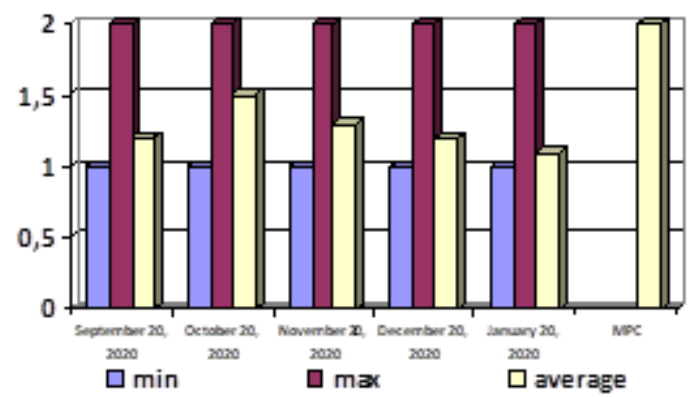

Figure 5. The content of hydrogen sulfide in the point of Mirny AOR

The data for Mirny AOR show that there were no MPC exceedances for all indicators, only $1 \mathrm{MPC}\left(2 \mathrm{mcg} / \mathrm{m}^{3}\right)$ was noted for the maximum values, and there were no exceedances for the average and minimum values and they amounted to about $1 \mathrm{mcg} / \mathrm{m}^{3}$.

Figure 6 shows the indicators for item 6 of Steaming.

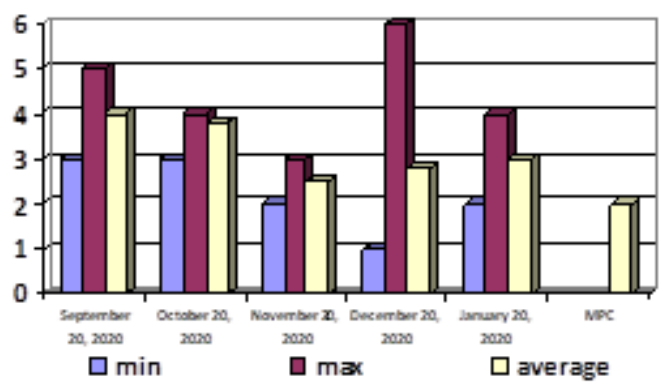

Figure 6. The content of hydrogen sulfide in the point of Steaming

Data on Steaming, AOR show that in general, the maximum permissible concentration exceeded from 1 to 3 times (2-6 $\left.\mathrm{mcg} / \mathrm{m}^{3}\right)$ at the maximum value. The average value was from 1.2 to 2 PDC $\left(2.5-4 \mathrm{mcg} / \mathrm{m}^{3}\right)$. By the minimum value, the data did not exceed the MPC.

Figure 7 shows the indicators for item 7 of Drag and drop AOR.

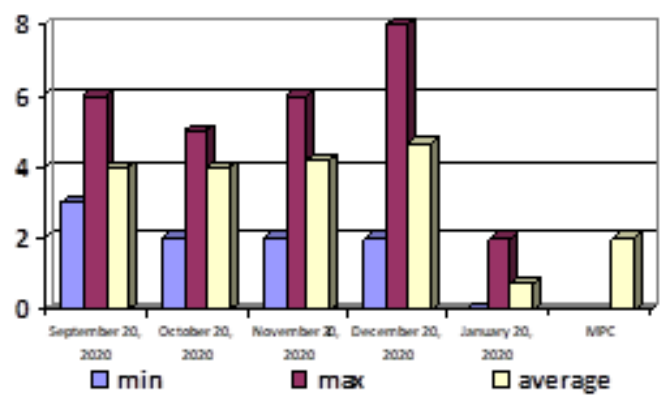

Figure 7. The content of hydrogen sulfide in the point of Drag and drop AOR

The data of Drag and drop AOR rebalance show that there was a slight excess of the minimum value of 1.5 MPC (3 $\left.\mathrm{mcg} / \mathrm{m}^{3}\right)$ in September, and in the rest of the period at the level of $1 \mathrm{MPC}\left(2 \mathrm{mcg} / \mathrm{m}^{3}\right)$, in January this value was at the level of $0 \mathrm{mcg} / \mathrm{m}^{3}$. According to the maximum values, they were at the level of 1-4 MPC (2-8 $\left.\mathrm{mcg} / \mathrm{m}^{3}\right)$. According to the average value, only in January it was lower than the MPC $\left(0.7 \mathrm{mcg} / \mathrm{m}^{3}\right)$, and in the rest of the period from 2-2.3 MPC $\left(4-4.7 \mathrm{mcg} / \mathrm{m}^{3}\right)$.

Figure 8 shows the indicators for item 8 of Himposylok AOR.

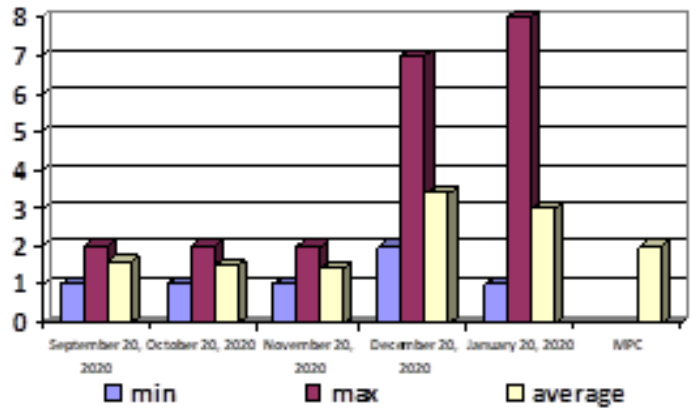

Figure 8. The content of hydrogen sulfide in the point of Himposylok AOR

As can be seen from the results at the Himposylok point of the AOR, the main indicators did not exceed the MPC in the autumn period and were in the range from 1 to $2 \mathrm{mcg} / \mathrm{m}^{3}$, while in the winter period they were $3.5-4 \mathrm{MPC}\left(7-8 \mathrm{mcg} / \mathrm{m}^{3}\right)$ at the maximum values.

Figure 9 shows a comparative analysis of all 8 points for the average indicators for the entire study period.

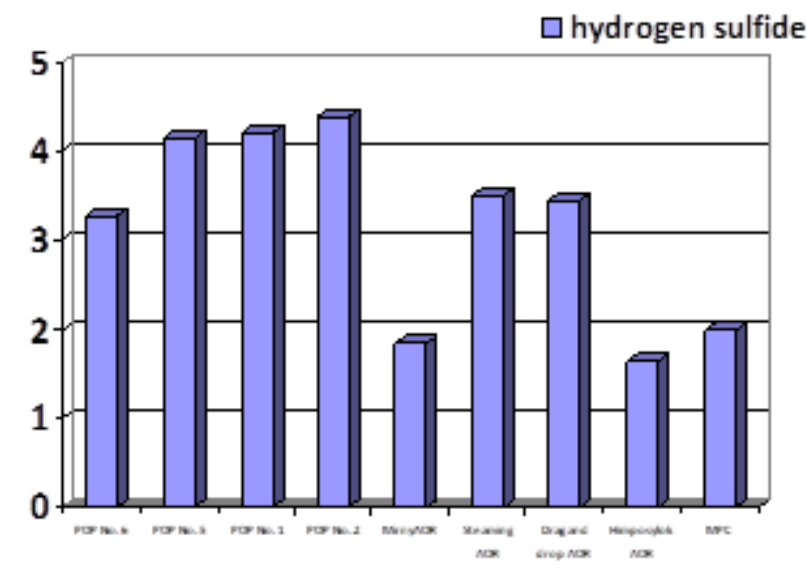

Figure 9. Comparative analysis of 8 points for the average indicators of hydrogen sulfide for the entire period of the study

Of the 8 points, only 2 did not exceed the MPC, these include Himposylok AOR and Mirny AOR, where the content of hydrogen sulfide was 0.82 and 0.92 MPC. At all other points, the content of hydrogen sulfide exceeded the MPC, so for example, at some points they were less than 2 MPC, for example, at POP No. 6 it is 1.64 MPC, at Drag and drop AOR it was $1.72 \mathrm{MPC}$, at Steaming AOR it was $1.76 \mathrm{MPC}$. At the other three points, the content of hydrogen sulfide was higher than 2 MPC, for example, at the point of POP No. 5 it was 2.07 MPC, at the point of POP No. 1 it was $2.1 \mathrm{MPC}$, at the point of POP No. 2 it was 2.19 MPC.

\section{CONCLUSIONS}

According to the analysis of data from automatic 
monitoring stations, significant excessed of the standard indicators of hydrogen sulfide (mainly in the evening and at night) was recorded at the stations of POP No. 1 and POP No. 2, which were located on Azattyk and Auezov Avenues, in the north-western part of the AOR at a distance of 1.5-2.5 km. This area was densely populated, which in turn had a strong impact on the health of the population, who constantly felt the smell of "rotten eggs". The source of hydrogen sulfide emissions had not been determined, but it was impossible to exclude the possible negative impact on the state of the atmosphere of the city of emissions of AOR, located near places with recorded excessed of the content of hydrogen sulfide in the atmosphere of the city. At the same time, at stations located at a close distance from the AOR or in other directions, the content of hydrogen sulfide was at the level of the MPC or slightly exceeded it. Perhaps this was due to the fact that the wind blows more often in the north-west direction. It was necessary to conduct regular monitoring studies in the city of Atyrau, as the population of the city constantly felt the environmental burden from the oil production and refining industries, including the impact of hydrogen sulfide. To reduce this impact, it is necessary to carry out measures to reduce the content of hydrogen sulfide, which should primarily be aimed at greening the region.

\section{REFERENCES}

[1] Baktybayeva, Z.B., Suleymanov, R.A., Valeev, T.K., Rakhmatullin, N.R. (2018). Assessment of the impact of the oil refining and petrochemical industries on the ecological and hygienic state of environmental objects and public health (literature review). Occupational Medicine and Human Ecology, 4: 12-24. (in Russian).

[2] Badalians Gholikandi, G., Lashkari, M., Orumieh, H.R., Tashaouie, H.R., Haddadi, S. (2010). Assessment of air pollution from Tehran-Mehrabad airport, Iran. International Journal of Sustainable Development and Planning, 5(2): 185-191. https://doi.org/10.2495/SDPV5-N2-185-191

[3] Yessenamanova, M.S., Yessenamanova, Zh.S., Tlepbergenova, A.E., Abdinov, R.Sh., Ryskalieva, D.K. (2020). Desertification assessment of the territory of Atyrau region. IOP Conference Series: Earth and Environmental Science, 421(6): 062005.

[4] Beksultan, M.Z., Bazarbayeva, T.A. (2016). Ecological situation of Atyrau region. International Student Scientific Bulletin, 3-4. (in Russian).

[5] Yessenamanova, M.S., Tekeyeva, A.A., Yessenamanova, Z.S., Tlepbergenova, A.E. (2020). Assessment of the impact of indicator air pollutants in Atyrau city on public health. IOP Conference Series: Earth and Environmental Science, 548(6): 062018.

[6] Yessenamanova, M.S. (2020). Assessment of individual risk criteria for the disposal of radioactive waste. IOP Conference Series: Materials Science and Engineering, 734(1): 012169.

[7] Esenamanova, M.S., Dyusupov, E.E., Esenamanova, Z.S., Tlepbergenova, A.E., Dyusekenova, A.E., Temirbekov, T.T. (2019). Monitoring of atmospheric air in the territory of the Atyrau oil refinery. Achievements of Modern Natural Science, 3(1): 46-50, (in Russian).

[8] Yessenamanova, M.S., Sangajieva, L.K., Yessenamanova, Z.S., Tlepbergenova, A.E. (2020). Migratory activity at the landfill site of microelements of the Caspian depression. News of the National Academy of Sciences of the Republic of Kazakhstan, Series of Geology and Technical Sciences, 1(439): 155-163. https://doi.org/10.32014/2020.2518-170X.19

[9] Eunjung, L., Omar, M., Lee, A.S.W., James, D. (2016). Effect of environmental exposure to hydrogen sulfide on central nervous system and respiratory function: a systematic review of human studies. International Journal Occupational and Environmental Health, 22(1): 80-90, (in Russian). https://doi:10.1080/10773525.2016.1145881

[10] Efimova, N.V., Tikhonova, I.V., Zhigalova, O.V., Yu, K.O., Abramatets, E.A., Rychagova, O.A., Taranenko, N.A., Lisetskaya, L.G. (2009). Inhalation risk to public health in the territories of chemical enterprises (on the example of the Irkutsk region). Siberian Medical Journal (Irkutsk), 5(88): 111-114, (in Russian).

[11] Yeler, D.Y., Aydin, M., Hocaoğlu, P.T., Koraltan, M., Özdemir, H., Kotil, T., Gül, M. (2016). Ultrastructural changes in epithelial cells of rats exposed to low concentration of hydrogen sulfide for 50 days. Ultrastructural Pathology, 40(6): 351-357. https://doi:10.1080/01913123.2016.1234530

[12] Ulivanova' G., Fedosova, O., Antoshina, O. (2020). Complex evaluation of the modern atmospheric air of city ecosystems. International Scientific-Practical Conference "Agriculture and Food Security: Technology, Innovation, Markets, Human Resources", 17. https://doi.org/10.1051/bioconf/20201700088

[13] Ledentsova, E.E., Zaitseva, N.V., Zemlyanova, M.A. (2004). Assessment of the impact of oil refining industry emissions on public health. Hygiene and Sanitation, 1: 10-12, (in Russian).

[14] Alimbaev, T., Yermagambetova, K., Kabyltayeva, S., Issayev, A., Kairat, Z., Mazhitova, Z. (2020). Environmental problems of the oil and gas industry in Kazakhstan. E3S Web of Conferences, 215: 03008. https://doi.org/10.1051/e3sconf/202021503008

[15] Mukusheva, G.K., Sarsembiyeva, N.S. (2017). Study of emissions of polluting substances from ANPZ to environment and development of recommendations for their decrease. News of the National Academy of Sciences of the Republic of Kazakhstan, Series of Social and Human Sciences, 324(2): 225-229. https://doi.org/10.32014/2019.2224-5294.73

[16] Current and forecast data of atmospheric air quality of the Republic of Kazakhstan. (in Russian). http://apps.kazhydromet.kz:3838/app dem visual/.

\section{NOMENCLATURE}

$\begin{array}{ll}\mathrm{H}_{2} \mathrm{~S} & \text { hydrogen sulfide } \\ \text { MPC } & \text { maximum permissible concentration } \\ \text { AOR } & \text { "Atyrau Oil Refinery" } \\ \text { POP } & \text { Pollution Observation Point }\end{array}$

